\title{
Causes and Coping Strategies for Stress among Employee
}

\author{
Afnan khan, Alamgir Khan*, Salahuddin Khan, Sami ullah Khan and Muhammad Khushdil Khan \\ Department of Sports Sciences and Physical Education, Gomal University, Pakistan
}

Submission: January 05, 2018; Published: January 16, 2018

*Corresponding author: Alamgir Khan, Department of Sports Sciences and Physical Education, Gomal University, Pakistan, Email: alamgir1989@hotmail.com

\begin{abstract}
Stress is the physical and psychological response of the body to events that make you feel threatened or upset your balance in some way. This study was undertaken to assess the causes and coping strategies for stress among employees. In this regard, structured and pre-tested questionnaire was designed to include demographics, socio-economic aspects and set research objectives. All the Employees of Gomal University Khyber Pakhtunkhwa, Pakistan were taken as population of the study. The collected data were tabulated and analyzed by using percentile as statistical tool. After data analysis, the researcher arrived at conclusion that Negative attitude of boss, Harsh attitude of boss, Unnecessary work load, Insufficient salary, Lack of co-operation on part of boss are the basics causes of stress among the employees similarly Friendly attitude of boss, Sufficient work load on the basis employ abilities and capabilities, Sufficient salary, Co-operation on part of boss are those strategies through which we can easily reduce the stress among the employees. The researcher also concluded that Co-operation on part of colleague, Job satisfaction, Motivation, Appreciation, Incentives or awards on the basis of performance are those strategies through which we can easily reduce the stress among the employees.
\end{abstract}

Keywords : Stress; Employees; Causes; Coping strategies

\section{Introduction}

Stress is the physiological and psychological response to circumstances that threatens or challenges us and that involve some specific kind of adjustment. Peoples' lives these days have become so intense and stressful. If observed thoroughly, as equated to past times, there are more things to do, more people to please, more complexities, competition, misunderstandings, anxieties in an individual's life whereas there is less tolerance, time, endurance, understanding and acceptance. To make things worse even though we are surrounded by so many people, it's hard to find someone who will not judge, prosecute or label us and who is willing to hold our hand and navigate us through the stormy seas of our daily lives and our inner conflicts [1]. The Major Stress of Employees Teachers, teachers and teachers will continue to experience significant stress and stress, which may be difficult, sometimes difficult, for students to take on school education. Many educators teach in their professions and love their work, but they are not stress-free. As teachers, we know how our moods influence classroom instruction. During school hours and evenings, we can take time to manage stress and become peaceable and effective teachers. This research is designed to introduce a few techniques to help educate the educators at various colleges and to help them find themselves in a safe environment in the future [2].
The idea is to understand the actual causes which are causing stress to the teaching staff in colleges and to analyze the same. The motive of the study is also to suggest the remedial measures in order to reduce the level of stress and help in improving the work efficiency of the affected class [3]. Stress is a physiological retort of the body to life situations, including both happy and unhappy events. Any time a demand is made to a person to make some sort of adjustment; it can lead to increased stress. Typical stress issues may include relationships, positive or negative job changes, children, fears and illness. Individuals with autism tend to have unusually high levels of stress. The source of this stress can be associated with social situations, changes in routine, fear, interruption of a preservative routines or an inability to effectively communicate. Stress and anxiety may take the form of screaming, throwing things, hitting, and swearing or oppositional behavior. Such high levels of stress should be addressed as a part of behavior intervention plans designed to reduce such unwanted [3].

\section{Statement of the Study}

It is commonly observed that work related stress is the main issue in various fields particularly in educational institutions. On the other hand it is almost associated to departmental responsibilities. What kind of strategies may be made for the 
removal of stress among the employees? For the purpose to discover the fact the researcher intend to conduct a research study under the title Causes and coping strategies for stress among employees of Gomal University Dera Ismail khan.

\section{Objectives of the Study}

a) To assess the causes of stress among employees working in Gomal University Dera Ismail Khan.

b) To evaluate the coping strategies for stress among employees working in Gomal University Dera Ismail Khan.

\section{Significance of the Study}

As it is fact that stress is psychological condition effecting badly on the overall performance of a person. There are so many factors cause stress among the peoples, what are all those factors which cause stress among the people? How one can avoid stress? And what kind of strategies adopted by a person for reducing or avoiding stress? So this particular research study will help to understand the factors caused stress among the different working groups. Beside this, it will also help to understand the coping strategies among the people.

\section{Research Questions}

a) What are the causes of stress among employees working in Gomal University Dera Ismail Khan?

b) What are the coping strategies among employees for avoiding stress?

\section{Review of Related Literature}

Stress has been defined in different ways over the years. Originally, it was conceived of as pressure from the environment, then as strain within the person. The generally accepted definition today is one of interaction between the situation and the individual. It is the psychological and physical state that results when the resources of the individual are not sufficient to cope with the demands and pressures of the situation. Thus, stress is more likely in some situations than others and in some individuals than others. Stress occurs when there is a perceived discrepancy between the demands of a situation and an individual's [4]. Although some stress is a natural and inevitable part of our lives, feeling burdened or unable to cope can be problematic and can seriously affect your mental and physical well-being. Stress can be effect of both affirmative and destructive experiences, and it is an essential part of our lives. Some stress continues to be a helpful part of our modern lives since it motivates us to accomplish tasks or make needed changes. We all feel the pressure of our environment during times of transition and in preparation for significant life events.

\section{Stress a problem}

Signs of stress can be seen in people's behavior, especially in changes in behavior. Acute responses to stress may be in the areas of feelings (for example, anxiety, depression, irritability, fatigue), behaviour (for example, being withdrawn, aggressive, tearful, unmotivated), thinking (for example, difficulties of concentration and problem solving) or physical symptoms (for example, palpitations, nausea, headaches). The effect of daily stressors can be particularly harmful to the psychological and physiological wellbeing of people [5]. If stress persists, there are changes in neuroendocrine, cardiovascular, autonomic and immunological functioning, leading to mental and physical ill health (for example anxiety, depression, heart disease). Delahaij et al. [6] clarify stress intense a bio psychosocial approach, suggesting that stressful reactions affect the emotional, physiological and cognitive state of an individual.

\section{Causes of Stress}

Stress comes in many forms and affects people of all ages and all walks of life. No external standards can be applied to predict stress levels in individuals - one need not have a traditionally stressful job to experience workplace stress, just as a parent of one child may experience more parenting stress than a parent of several children. The degree of stress in our lives is highly dependent upon individual factors such as our physical health, the quality of our interpersonal relationships, the number of commitments and responsibilities we carry, the degree of others' dependence upon us, expectations of us, the amount of support we receive from others, and the number of changes or traumatic events that have recently occurred in our lives. Some of the common causes of stress include:

i. Life events: Such as divorce or separation, death of a loved one, the birth of a child etc.

ii. Physical stressors: Such as physical injury, chronic pain, and unsatisfied physical needs such as hunger, thirst or lack of sleep

iii. Daily events: Such as traffic congestion, working overtime, deadlines etc.

iv. Environmental stressors: Such As Pollution, Weather Extremes or Excessive Noise

\section{Effects of Stress on the Body Performance}

Stress effects on the overall performance of athlete. How it effects on the performance of athlete? Stress affects the glands systems of the body. Glands maintain the different body functions of the body such as digestion of the body, temperature regulations and so on. When the glands systems become unbalance than body leads to different problems such as given in the picture of next slid.

\section{How we Can Reduce Stress}

An individual's ability to handle stress is determined by the relationship between personal attributes such as cognitive, emotional and behavioral development [6]. In the time of great stress or adversity, it is always best to keep yourself busy, to plow your anger and your energy into something positive. When you are in stress than keep himself/herself busy in such type of activities which make you relax and reduce you stress. In this 
regard different kind of exercise is commonly used. But the best exercise is called or known as meditation.

\section{Practice of Meditation}

a. Close your eyes

b. Set relax

c. Breathe normally

d. Remember your past (such as you were a child and going to school)

e. School is started

f. School timing end now

g. You are going back to your home

\section{Islamic way of Meditation for Reducing Stress}

In Islamic point of views, Namaz is the best type mediation. Such as our holy prophet Hazrat Muhammad (SAW) says "Namaz mera anakoo ki tandak hay". It is also says that "Namaz dil ki sakoon hay". It means that with the help of Namaz we can reduce the stress of our body. It is also says that "sakoon dil ka lya ALLAH ki yad kafee hai".

\section{Method and Material}

The population of this particular study consists of all the employees of Gomal University (GU) dera Ismail khan (dik) Khyber Pakhtunkhwa (kpk) Pakistan. The total numbers of employees are 1365 in Gomal University. So it is very difficult for the researcher to contact each and every respondent. To overcome this difficulty the researcher selected $20 \%$ from whole population as sample by using convenient sampling technique. Thus, 150 employees were taken as a sample from employees of Gomal University. Data were collected through a structured and pre-tested questionnaire. The questionnaire was distributed among the students (through co-author \& $\mathrm{m}$. Phil sports sciences session 2017-19 scholars) and collected back after being filled by the respondents. The data were tabulated and analyzed by using percentile as a tool of statistics.

\section{Presentation and Analysis of Data}

The collected data was tabulated and the researcher used mean as a statistical tool to test each Research question. The Table 1 depict that the Average percentage of Agree is 69.42\%, Disagree is $19.89 \%$ and Undecided is $10.65 \%$. The above percentages of Agree shows that majority of the respondents agree with the statement that Negative attitude of boss, unnecessary work load, insufficient salary and lack of co-operation, motivation and appreciation are causes for stress among employees. The Table 2 depict that the Average percentage of Agree is $79.0 \%$, Disagree is $10.66 \%$ and Undecided is $10.28 \%$. The above percentages of Agree shows that majority of the respondents agree with the statement that Negative attitude of boss, unnecessary work load, insufficient salary and lack of co-operation, motivation and appreciation are causes for stress among employees.

Table 1: Showing Causes of stress for employees.

\begin{tabular}{|c|c|c|c|c|c|c|c|}
\hline S. No & Causes of stress for employees & A & \%A & UD & \%UD & D & \%D \\
\hline 1 & Negative attitude of boss & 80 & 53.33 & 30 & 20 & 40 & 26.67 \\
\hline 2 & Unnecessary work load & 90 & 60 & 30 & 20 & 30 & 20 \\
\hline 3 & Insufficient Salary & 99 & 66 & 11 & 7.3 & 40 & 26.6 \\
\hline 4 & Lack of cooperation on part of boss & 110 & 73.33 & 10 & 6.66 & 30 & 20 \\
\hline 5 & Lacking of job satisfaction & 120 & 80 & 08 & 5.33 & 22 & 14.66 \\
\hline 6 & Lacking of motivation of parts of boss & 110 & 73.33 & 15 & 10 & 25 & 16.66 \\
\hline 7 & Lack of appreciation & 120 & 80 & 08 & 5.33 & 22 & 14.66 \\
\hline & Average Percentage (Total): & $69.42 \%$ & & $10.65 \%$ & & $19.89 \%$ & \\
\hline
\end{tabular}

Table 2: Showing ccoping strategies among employees for avoiding stress.

\begin{tabular}{|c|c|c|c|c|c|c|c|}
\hline S. No & $\begin{array}{c}\text { Coping strategies among employees for } \\
\text { avoiding stress }\end{array}$ & $\mathbf{A}$ & $\mathbf{\% A}$ & $\mathbf{U N}$ & $\mathbf{\% U N}$ & $\mathbf{D}$ & \%D \\
\hline 1 & Positive attitude of boss & 130 & 86.66 & 08 & 5.33 & 12 & 08 \\
\hline 2 & Sufficient salary & 120 & 80 & 16 & 10.66 & 14 & 9.33 \\
\hline 3 & Cooperation on part of boss & 122 & 81.33 & 18 & 12 & 10 & 6.66 \\
\hline 4 & Good working atmosphere & 123 & 82 & 12 & 08 & 15 & 10 \\
\hline 5 & Job satisfaction & 120 & 80 & 09 & 6 & 21 & 14 \\
\hline 6 & Motivation & 115 & 76.66 & 15 & 10 & 20 & 13.33 \\
\hline 7 & Appreciation & 100 & 66.66 & 30 & 20 & 20 & 13.33 \\
\hline & Average Percentage (Total): & $79.0 \%$ & & $10.28 \%$ & & $10.66 \%$ & \\
\hline
\end{tabular}




\section{Conclusion}

Based on analysis, the researcher arrived at conclusion that Negative attitude of boss, Harsh attitude of boss, Unnecessary work load, Insufficient salary, Lack of co-operation on part of boss are the basics causes of stress among the employees. The researcher also concluded that Lack of co-operation on part of colleague, Lacking of job satisfaction, Lacking of motivation on part boss, Lack of appreciation, Less incentives are the basics causes of stress among the employees. The researcher also concluded that Lack of good working atmosphere, Undue restriction on part of boss, Lacking of provision of leisure time for employees, Unavailability of basic facilities of recreational activities, Improper arrangement for recreational activities for employees are the basics causes of stress among the employees.

The researcher also concluded that Positive attitude of boss, Friendly attitude of boss, sufficient work load on the basis employ abilities and capabilities, sufficient salary, Co-operation on part of boss are those strategies through which we can easily reduce the stress among the employees. The researcher also concluded that Co-operation on part of colleague, Job satisfaction, Motivation, Appreciation, Incentives or awards on the basis of performance are those strategies through which we can easily reduce the stress among the employees. The researcher also concluded that Good working atmosphere, Favor of employees on part of boss, Provision of leisure time for recreational activities, Provision of basics facilities for leisure time recreational activities Proper arrangement for recreational activities for employees are those strategies through which we can easily reduce the stress among the employees.

\section{Recommendations}

I. Unnecessary work load(the researcher found that the main cause of work related stress for subordinates is harsh and negative attitude of boss, however, the researcher recommended that, boss should be nice with their subordinates and should call meeting for any problem in secrecy to boost their confidence and working capacity).

II. Insufficient salary (concerned authorities should be offer sufficient salary and incentives for workers to boost their interest in the work).
III. Lack of co-operation on part of boss (boss and other skilled colleagues should be cooperative with the worker to limited their working problems with own experience and intellectual power).

IV. Lack of appreciation (appreciation is very essential for workers the concerned authorities should give prize and awards on best work in the organization to enhanced their interest through appreciation).

V. Positive attitude of boss (the authorities must have positive attitude to their subordinate.

VI. Boss may encourage their collages for the improvement of their performance).

VII. Sufficient work load on the basis employ abilities and capabilities.

VIII. Sufficient work load may be given to employees).

IX. Co-operation on part of boss (boss should be cooperative with his colleague. Cooperation is the main coping strategies for work related stress).

\section{References}

1. Davis Martha, Robbins Elizabeth Eshelman, Matthew McKay (2000) The Relaxation \& Stress Reduction Workbook ( $5^{\text {th }}$ edn), Oakland, CA: New Harbinger Publications.

2. Hart Anna (2010) Stress Management for Students. Ezine Articles Submission-Submit your best Quality Original Articles for Massive Exposure, Ezine Publishers.

3. Malgaj Luka (2010) Top 7 Stress Management Tips For Students. Ezine Articles Submission-Submit Your Best Quality Original Articles For Massive Exposure, Ezine Publishers.

4. Caltabiano ML, Sarafino E, Byrne D (2008) Health psychology: Biopsychosocial interactions $\left(2^{\text {nd }} e d n\right)$. John Wiley \& Sons, Milton, Australia, pp. 758.

5. Yahav R, Cohen M (2008) Evaluation of a cognitive-behavioral intervention for adolescents. International Journal of Stress Management 15(2): 173-188.

6. Delahaij R, Van Dam K, Gaillard AWK, Soeters J (2011) Predicting performance under acute stress: The role of individual characteristics. International Journal of Stress Management 18(1): 49-66. 
This work is licensed under Creative

Commons Attribution 4.0 Licens

DOI: 10.19080/JPFMTS.2018.01.555567

\section{Your next submission with Juniper Publishers} will reach you the below assets

- Quality Editorial service

- Swift Peer Review

- Reprints availability

- E-prints Service

- Manuscript Podcast for convenient understanding

- Global attainment for your research

- Manuscript accessibility in different formats ( Pdf, E-pub, Full Text, Audio)

- Unceasing customer service

Track the below URL for one-step submission https://juniperpublishers.com/online-submission.php 